\title{
Demographic Processes Allow Echinochloa crus-galli to Compensate Seed Losses by Seed Predation
}

\author{
Heike Pannwitt *,t, Paula R. Westerman, Friederike De Mol and Bärbel Gerowitt \\ Faculty of Agricultural and Environmental Sciences, Crop Health Group, University of Rostock, \\ 18051 Rostock, Germany; pr.westerman@gmail.com (P.R.W.); friederike.de-mol@uni-rostock.de (F.D.M.); \\ baerbel.gerowitt@uni-rostock.de (B.G.) \\ * Correspondence: heike.pannwitt@julius-kuehn.de \\ + Current Address: Julius Kühn-Institute (JKI), Federal Research Centre for Cultivated Plants, Institute for \\ Biosafety in Plant Biotechnology, 06484 Quedlinburg, Germany.
}

\begin{abstract}
The effect of weed management that targets the seed stage on subsequent life stages is largely unknown. Post-dispersal seed predation reduces the number of seeds from the soil surface before the seeds contribute to the seedbank. Density-dependent processes can mitigate the effect of seed predation in subsequent life stages. In this study, we tested if (i) targeting the seed stage affects the subsequent seedling stage; (ii) if density-dependent mortality in subsequent life stages partly compensates seedling abundance; and (iii) if the magnitude of final seed production depends on seed predation. We fully parameterized a model for the summer-annual weed Echinochloa crus-galli (L.) P. Beauv. Field data from three maize fields in north-eastern Germany were obtained, in the presence or absence of seed predation and different population levels of the weed species. Seeds of E. crus-galli were applied in autumn and the number of seedlings, adult plants, and seed production per $\mathrm{m}^{2}$ was determined the following season. Seed predation reduced the number of seedlings. Density-dependent mortality during the seedling stage increased fecundity with decreasing seedling density, and, thus, compensated for lower numbers of seedlings. The final level of seed production per $\mathrm{m}^{2}$ did not depend on seed predation and initial population densities, but differed among fields. We conclude, solely targeting the seed stage can scarcely limit the population growth of E. crus-galli.
\end{abstract}

Keywords: weed seed predation; density-dependence; constant final seed production; compensation; maize

Academic Editors: Ilias Travlos,

Nicholas Korres and Rafaels De

Prado

Received: 31 January 2021

Accepted: 15 March 2021

Published: 17 March 2021

Publisher's Note: MDPI stays neutral with regard to jurisdictional claims in published maps and institutional affiliations.

\section{Introduction}

The demography of annual plant species that reproduce by seeds can be described by their different life stages. They germinate from seeds, establish flowering adult plants, set seeds that are disseminated on the ground, and die [1]. The primary source of an annual plant population is the weed seedbank. Targeting the seed stage and reducing the size of the seedbank limit the establishment of plants from seeds in the long term $[2,3]$. Weed management with a focus on the immediate control, however, mainly targets the seedling stage, since seedlings are easy to locate and vulnerable to disturbance [2]. Some seedlings, however, can survive weed control, making weed management less effective. The effectiveness of management depends on both the rate of mortality at the targeted life stage, and its residual effect on escaped individuals. In particular, density-dependent processes in weed populations can compensate for the mortality at any particular life-cycle stage. Thus, to evaluate the population growth, the effects of a specific management strategy on all life stages of an annual weed must be considered.

Post-dispersal seed consumption targets the seed stage, which prevents the contribution of seeds to the seedbank. These seeds are predated as long as they are on the soil surface and not incorporated into the soil [4]. Thus, mortality due to seed predation targets exclusively the top-soil seeds. Annual seed losses by seed predation vary between $8 \%$ and 
$70 \%[5,6]$, and depend on weed species [7,8], seed density [9-12], type of seed predator [13], field management [14] and landscape complexity $[15,16]$. Annual seed losses to seed predation can be substantial, but empirical evidence for the effect on weed population densities is scarce. A modelling approach showed that weed populations decline if annual seed losses are at least $40 \%[17,18]$. To our knowledge, experimental approaches addressing the effect of post-dispersal seed predation on other life stages are limited to the seedling stage $[19,20]$. Experiments demonstrating the effect of seed predation on other non-target life stages, however, would fill a knowledge gap [21,22]. Understanding the impact of seed predation on each non-target life stage would clarify its potential to control weed species.

While seed predation can cause substantial seed losses, these losses could be compensated by density-dependent processes in the weed population that grow from the seed bank in the soil, and would mitigate the potential of seed predation to manage weeds [23]. In density-dependent processes, mortality rates change with the weed population density [24]. If the weed density is high, then on the one hand mortality is high but on the other hand the survival rate is low. Density-dependence has been recognized to influence different plant population life stages, such as seedling emergence [25], seedling survival [26,27], and fecundity $[24,28]$. The later means that the fecundity of individual plants within high population densities decreases. Conversely, fecundity increases within low population densities. Then, at least partly, plant populations can compensate for seed losses. Compensation can result in a density-independent seed production per unit area. Weed management identifies solutions to prevent the growth of weed populations by producing new seeds. This requires an understanding of the potential of weed species to compensate for seed losses.

Seed predation is likely to contribute to weed management if there is a small weed seedbank and the weed species regenerate by seeds [23]. A large ambient weed seedbank, in contrast, would buffer losses of freshly shed seeds by seed predation. This means seed losses due to seed predation will not reduce the relative number of emerging seedlings from a large seedbank and thus, the influence of seed predators to reduce weed populations is limited.

Echinochloa crus-galli (L.) P. Beauv., a typical summer-annual weed in maize fields in Germany [29], propagates via seeds. This species completes its life cycle within one cropping period. The weed easily adapts to increasing competition by reducing tillers and panicles [30]. One single plant can produce between 2000 and 400,000 seeds [30-32].

The management of E. crus-galli relies mainly on chemical control targeting the seedling stage. Herbicide resistance has been found for E. crus-galli [33], which calls for the use of additional alternative management strategies. Seed predation may contribute to the management of E. crus-galli. The response of E. crus-galli to seed predation, however, has not been examined to date.

In this study system, seed predation over the winter was density-independent and seed predation rates were at a high level [12]. Hence, in the presence of seed predation, we assumed that the abundance of weeds in the next season would be reduced. We hypothesized that:

Targeting the seed stage affects the density of the subsequent seedling stage.

Density-dependent mortality in subsequent life stages partly compensates seedling abundance. The magnitude of the final seed production depends on seed predation.

\section{Materials and Methods}

In the present study, we quantified the demography of E. crus-galli in relation to whether or not the seed stage was targeted by post-dispersal seed predation. In northeastern Germany, a field experiment was conducted in three intensively managed agricultural fields (continuous maize crops that were minimally tilled) with no seeds of E. crus-galli in the seedbank. Echinochloa crus-galli populations were introduced to the fields at different densities, and with or without shielding from seed predation. For each population, the currently active life stages were determined. Counts determined for the spring seedbank, seedling stage, adult plant stage, and seed production per unit area and per individual 
plant were used to estimate the transition probability between life stages as a function of seed density. Next, the effects of density-dependent mortality on the different life stages were estimated.

\subsection{Study Sites and Experimental Design}

The experiment was carried out in three continuous managed maize fields in northeastern Germany from August 2014 until October 2015. All three fields had a history of at least three years of continuous maize cultivation with minimal tilling. Fields differed in their location, size and soil type; field $1\left(53^{\circ} 33^{\prime} \mathrm{N}, 11^{\circ} 08^{\prime} \mathrm{E}\right)$ was 11.8 ha in size and had sandy soil. Field $2\left(53^{\circ} 97^{\prime} \mathrm{N}, 11^{\circ} 98^{\prime} \mathrm{E}\right)$ was 10.1 ha in size and the soil was loamy sand; field $3\left(54^{\circ} 02^{\prime} \mathrm{N}, 12^{\circ} 02^{\prime} \mathrm{E}\right)$ was 7 ha with sandy loam soil. In each field, the experiment was installed in a randomized block design to measure the demography of E. crus-galli. Maize crops grew from May until September or October in 2014 and 2015. The experiment consisted of six blocks $(10.5 \mathrm{~m} \times 13.5 \mathrm{~m})$ with 12 plots $(1.5 \mathrm{~m} \times 1.5 \mathrm{~m})$ where half the plots were surrounded by a plastic frame to prevent the access of seed predators (Figure A1). In the inner $0.5 \mathrm{~m} \times 0.5 \mathrm{~m}$ of each plot the fate of the seeds from E. crus-galli was measured. Before the start of the experiment, in each block, 20 randomly chosen soil samples were taken with an auger $(2.54 \mathrm{~cm})$ to a depth of $5 \mathrm{~cm}$, stepwise processed using an Elutriator (Elutriator E48X; Disema, Bellvis, Spain; [34]) and indicated that E. crus-galli was absent from the seedbank. In August 2014, in a pure stand of maize crop, E. crus-galli seeds were sown once at different densities $\left(300,600,1200,2400\right.$ seeds $\mathrm{m}^{-2}$; seed supplied by Appels Wilde Samen $\mathrm{GmbH}$, Darmstadt, Germany) with each density in two plots per block. In the other four plots per block, no seeds were added for the purpose of a control. The time of seeding coincided with the normal period of seed shedding and the normal seed predation period [4]. The applied densities were within the range of the size of typical ambient seedbanks of E. crus-galli in North-West Europe, ranging from 0 to 4050 seeds $\mathrm{m}^{-2}$ [35]. The highest applied density is expected to induce density-dependent effects [24].

Furthermore, the experiment was designed to measure the effect of three different factors (intraspecific and interspecific competition, post dispersal seed predation) on the demography of E. crus-galli. A factor, intraspecific competition, the competition between E. crus-galli without relevant competition with other weed species, was initiated in three blocks by the applied different densities of E. crus-galli. In these blocks, the competition with other weed species than E. crus-galli was avoided by applying herbicides (not affecting E. crus-galli) twice (May and June 2015) and hand weeding (for more details see [32]). The factor of interspecific competition was initiated in three randomly chosen blocks by applying herbicides only once (May 2015). While maize evenly grew within the blocks, here we refer to the interspecific competition as competition between E. crus-galli and other weed species. The factor of seed predation was investigated in all six blocks in plots by comparing plots that prevented seed predators' access to half of the plots by a $0.6 \mathrm{~m}$ high plastic frame with plots without plastic frame. Each frame was buried $0.2 \mathrm{~m}$ deep into the soil. Plastic frames were installed permanently; however, they were taken out short-term for maize harvest in September-October 2014 and maize sowing in May 2015.

Further management was similar in all three fields, including seedbed preparation, maize sowing, and application of fertilizer. The seedbed was prepared by mulching the soil. Maize was sown in rows $0.75 \mathrm{~m}$ apart with 9 seeds $\mathrm{m}^{-2}$. To ensure that the applied E. crusgalli seeds did not move from the plots, the soil at the center of each plot $(0.5 \mathrm{~m} \times 0.5 \mathrm{~m})$ was not disturbed either horizontally or vertically. For this reason, the application of manure before maize sowing was omitted. Instead, mineral fertilizer was applied to the crop at the three-leaf stage. The amount of applied fertilizer (field 1, $20 \mathrm{~kg} / \mathrm{ha} \mathrm{N}$ and $40 \mathrm{~kg} / \mathrm{ha} \mathrm{P}$; field 2, $140 \mathrm{~kg} / \mathrm{ha} \mathrm{N}$ and $60 \mathrm{~kg} / \mathrm{ha} \mathrm{K}$; field 3, $70 \mathrm{~kg} / \mathrm{ha} \mathrm{N}$ and $70 \mathrm{~kg} / \mathrm{ha} \mathrm{P}$ ) was in line with general farming practices. For more details about field management (seedbed preparation, maize sowing, the type and amount of herbicides, and harvest date) and preparation of E. crus-galli for sowing see [12]. 


\subsection{Determination of Number of Proportions of Different Life Stages of E. crus-galli}

\subsubsection{Spring Seedbank}

In March 2015, soil samples were taken from the enclosed plots that excluded seed predation to estimate the depletion of seeds over the winter due to germination or mortality. In the outer $50 \mathrm{~cm}$ wide perimeter of each plot, 40 randomly chosen soil samples were taken with an auger $(2.54 \mathrm{~cm})$ to a depth of $5 \mathrm{~cm}$. The samples were stored at $4{ }^{\circ} \mathrm{C}$ until further processing to retrieve the seeds from the soil. The seeds in the soil samples were separated stepwise from organic material and larger sand particles using an Elutriator (Elutriator E48X; Disema, Bellvis, Spain; [34]), and apparently intact seeds (full and sound) were counted. Analysis showed that the mortality of seeds over winter was affected neither by the three fields nor by the density of E. crus-galli. Thus, the values were pooled to obtain a single mean proportion for mortality of seeds during the winter of 0.012 [12].

\subsubsection{Seedlings}

Emerged seedlings were counted in the central $0.5 \mathrm{~m} \times 0.5 \mathrm{~m}$ of each plot. From May until August 2015, counting was repeated every other week. Except in October and November 2014 and August and September 2015, seedlings were counted once a month. Seedlings that emerged in autumn 2014 died during the winter of 2014-2015. To follow the fate of the seedlings throughout the season, each seedling was marked with a toothpick. In this study, weed seedlings were pooled to a single cohort, because the majority of seedlings that survived to grow to adult plants had emerged within a narrow period between late May and June.

\subsubsection{Adult Plants}

Adult plants, i.e., plants that survived the seedling stage and developed panicles, were counted prior to maize harvest in October 2015. In the inner $0.5 \mathrm{~m} \times 0.5 \mathrm{~m}$ of each plot, adult plants were cut down to ground level and the panicles separated from the plants.

\subsubsection{Seed Production}

For each plot, seed production per square meter $\left(\mathrm{m}^{-2}\right)$ and fecundity (number of seeds per plant) was estimated by using the relationship between the number of seeds per panicle dry weight [32]. At the field scale, the relationship of the number of seeds per panicle dry was stable across E. crus-galli density, time of seedling emergence, interspecific competition with other weeds, and seed predation [32]. Depending on the field, panicle dry weight explained $95 \%$ (field 1), $86 \%$ (field 2), and $85 \%$ (field 3) of the variability in seeds per E. crus-galli panicle. To prepare for estimation of seed production $\mathrm{m}^{-2}$ and fecundity, seeds were collected by wrapping panicles in a perforated and air-permeable bag (Crispac bag, $150 \mathrm{~mm} \times 300 \mathrm{~mm}$, pores $2 \mathrm{~mm}$ diameter, Baumann Saatzuchtbedarf, Waldenburg, Germany) at the beginning of flowering, and the dry weight of the panicle, including seeds, was determined. Field-specific regressions of the number of seeds per panicle dry weight were used to estimate seed production $\mathrm{m}^{-2}$ based on the total number of seeds produced in the inner $0.5 \mathrm{~m} \times 0.5 \mathrm{~m}$ of each plot.

\subsubsection{Seed Predation}

The main seed predators, trapped after sowing E. crus-galli in the three experimental fields, were granivorous rodents and carabid beetles. For further details on trapping, we refer to [12]. During seed exposure between August 2014 and March 2015, the response of seed predators did not depend on E. crus-galli seed density. The seed predation rates varied between fields (mean $\pm \mathrm{sd}$; field 1, $0.62 \pm 0.28$; field 2, $0.38 \pm 0.28$; field 3, $0.70 \pm 0.17$ ) [12].

\subsubsection{Statistical Analysis}

We tested the effect of the three different factors intra- and interspecific competition and seed predation on the fecundity and the transition probability between different life 
stages. Fecundity was calculated by the quotient of the number of seeds produced per $\mathrm{m}^{2}$ and the number of adult plants per $\mathrm{m}^{2}$. The life stages include the transition from: the spring seedbank $\mathrm{m}^{-2}$ to seedlings $\mathrm{m}^{-2}$ (seedling emergence) seedlings $\mathrm{m}^{-2}$ to adult plants $\mathrm{m}^{-2}$ (seedling survival) adult plants $\mathrm{m}^{-2}$ to seed production $\mathrm{m}^{-2}$ (seed production $\mathrm{m}^{-2}$ ).

The best-fitting linear regression models (LM) were selected after log-transformation of count data. Log-transformation is a standard method for count data [36], with results being comparable to those of other studies. Explanatory variables were:

field $(1,2$, and 3$)$

seed predation $(+/-)$ as factor variable

initial density $(\log )$ of the relevant life stage and the second-degree polynomial interspecific competition with other weeds $(+/-)$ as factor variable first order interactions.

Model selection was via backward selection by using the F-test with $p \leq 0.05$ as the test criterion. In preliminary analyses, while data of all fields were analyzed together, transition probability between different life stages did not respond to interspecific competition (seedling emergence, $F=0.326, \mathrm{df}=1, p=0.207$; seedling survival, $F=0.391, \mathrm{df}=1$, $p=0.108$; and seed production $\mathrm{m}^{-2}, F=0.8623, \mathrm{df}=1, p=0.355$; fecundity, $F=1.121, \mathrm{df}=1$, $p=0.291$ ). Therefore, the factor of interspecific competition with other weeds was excluded. Furthermore, analysis on each life transition indicated a significant interaction between field and seed predation for seedling emergence $(F=4.909, \mathrm{df}=2, p=0.009)$, fecundity $(F=8.150, \mathrm{df}=2, p<0.001)$ and seed production $\mathrm{m}^{-2}(F=12.162, \mathrm{df}=2, p<0.001)$, but not seedling survival $(F=1.162, \mathrm{df}=2, p=0.327)$. Similarly, there was an interaction between field and initial density $(\log )$ of the relevant life stage for seedling emergence $(F=7.153, \mathrm{df}=2, p=0.001)$, seedling survival $(F=7.388, \mathrm{df}=2, p<0.001)$ and fecundity $(F=5.243, \mathrm{df}=2, p=0.006)$, but not seed production $\mathrm{m}^{-2}(F=1.8815, \mathrm{df}=2, p=0.156)$ (see Table A1). To avoid threefold interactions that are difficult to interpret, analysis was done field-specifically.

K-value analysis [36]:

$$
\mathrm{k}=\log \text { (initial density) } / \log (\text { final density), }
$$

was applied to quantify the magnitude of density-dependent mortality in life stages between fields, and in the absence and presence of seed predation. All analyses were carried out in $\mathrm{R}$ version 3.1.2 [37].

\section{Results}

When analyzed per field, the number of seedlings was reduced considerably by seed predation, which ranged from $40 \%$ to $50 \%$ in field 1, from 26 to $48 \%$ in field 2, and from 53 to $69 \%$ in field 3 (Figure 1).

Seed mortality was higher in the presence than in the absence of seed predation. Furthermore, seed mortality increased with density (Figure 2). In the presence or absence of seed predation, seedling emergence decreased with increasing seeding density (slope [initial density] $<1$; Table 1), except in field 3, where, in the absence of seed predation, seedling emergence increased with increasing seeding density (slope [initial density] $>1$; Table 1). 
Field 1
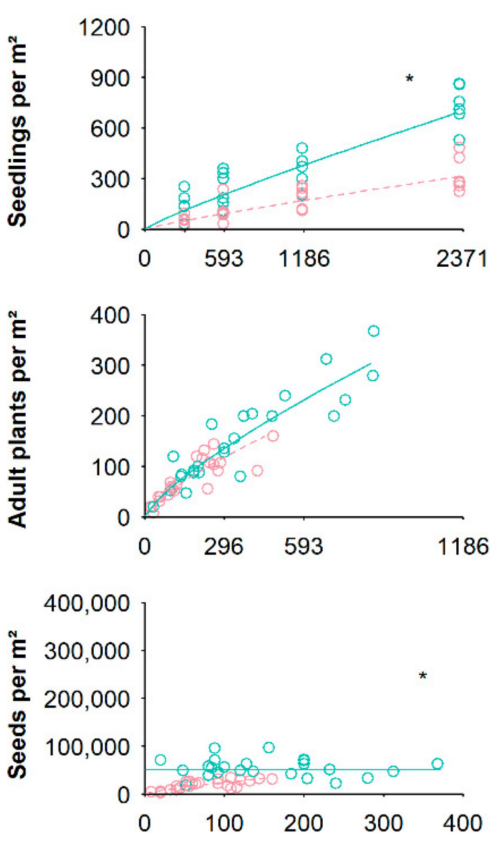

Field 2
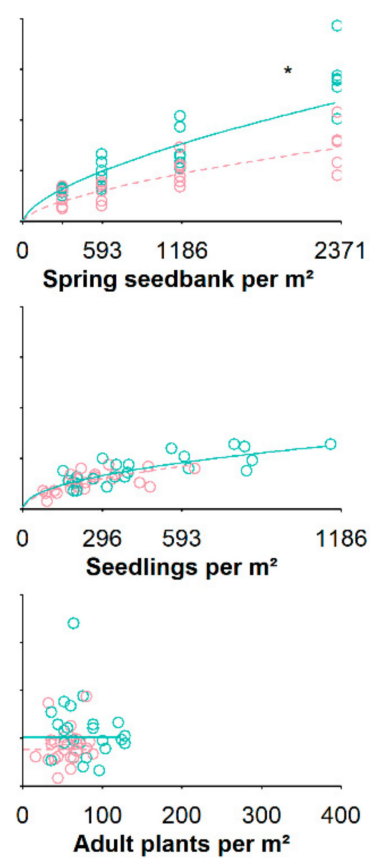

Field 3
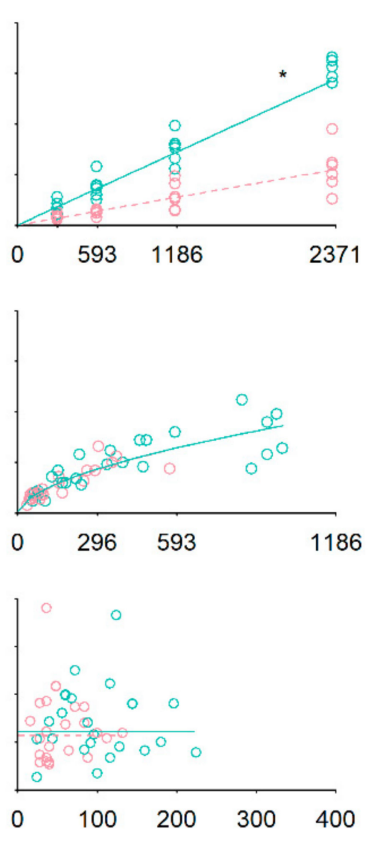

Figure 1. Back-transformed linear regression models showing the responses of transitions between life stages of Echinochloa crus-galli, i.e., seedling emergence, seedling survival, seed production $\mathrm{m}^{-2}$, to seed predation (red circles and dashed line) over the winter vs. no seed predation (green circles and solid line) over the winter, as a function of E. crus-galli density, in three maize fields in north-eastern Germany $(n=6)$. Panels labelled $\left(^{*}\right)$ indicate a significantly different $(p<0.05)$ response to seed predation.

Field 1

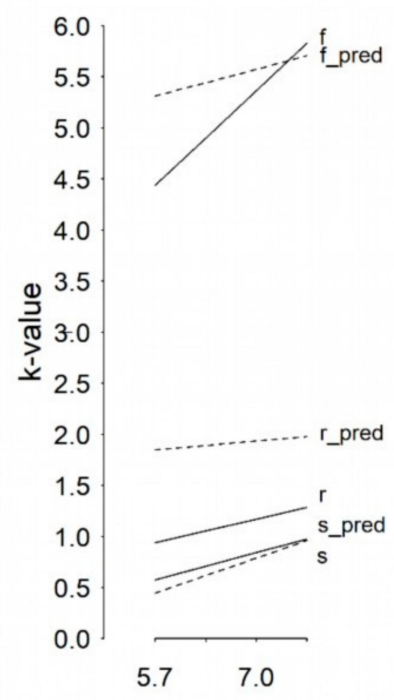

Field 2

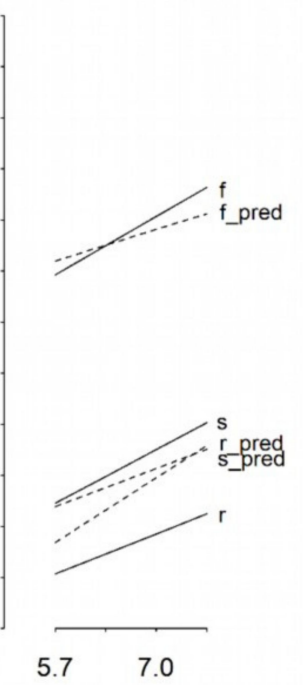

Field 3

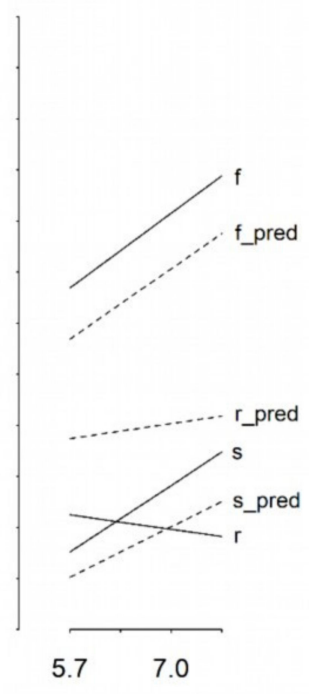

$\log \left(\right.$ Initial density of E. crus-galli [seeds $\left./ \mathrm{m}^{2}\right]$ )

Figure 2. K-values to determine the strength of density dependent mortality for seedling emergence (r), seedling survival (s), and seed production per plant (f) of Echinochloa crus-galli in the presence ("pred", dashed lines) or absence (solid lines) of seed predation in fields 1, 2, and 3 shown for each $\log$ (initial density of E. crus-galli [seeds $\left./ \mathrm{m}^{2}\right]$ ). Data predicted by using the models (see Table 1) calculate the k-values per log (initial density of E.crus-galli [seeds $\left./ \mathrm{m}^{2}\right]$ ). 
Table 1. Log-transformed parameter estimates, standard errors (SE), and $R^{2}$ values for linear regression models for Echinochloa crus-galli seedling emergence; seedling survival, seed production $\mathrm{m}^{-2}$ and seeds plant ${ }^{-1}$ as a function of seed predation ( ${ }_{\text {pred }}$ ) and density of the relevant life-cycle stage in fields 1,2 and 3.

\begin{tabular}{|c|c|c|c|c|c|c|c|c|c|c|}
\hline \multirow{2}{*}{ Model } & \multirow{2}{*}{ Parameter } & \multicolumn{3}{|c|}{ Field 1} & \multicolumn{3}{|c|}{ Field 2} & \multicolumn{3}{|c|}{ Field 3} \\
\hline & & Estimate & SE & $R^{2}$ & Estimate & SE & $R^{2}$ & Estimate & $\mathrm{SE}$ & $R^{2}$ \\
\hline \multirow[t]{2}{*}{$\begin{array}{c}\text { Seedling } \\
\text { emergence }_{\text {pred }}\end{array}$} & Intercept & -1.489 & 0.848 & $0.718^{*}$ & 1.755 & 0.633 & $0.605 *$ & -1.258 & 0.690 & $0.777^{*}$ \\
\hline & $\begin{array}{l}\text { Slope (initial } \\
\text { density) }\end{array}$ & 0.937 & 0.125 & & 0.543 & 0.093 & & 0.892 & 0.101 & \\
\hline \multirow[t]{2}{*}{$\begin{array}{c}\text { Seedling } \\
\text { emergence }\end{array}$} & Intercept & 0.003 & 0.836 & 0.675 & 1.068 & 0.415 & 0.861 & -1.705 & 0.473 & 0.918 \\
\hline & $\begin{array}{l}\text { Slope (initial } \\
\text { density) }\end{array}$ & 0.834 & 0.123 & & 0.718 & 0.061 & & 1.102 & 0.069 & \\
\hline \multirow{2}{*}{$\begin{array}{l}\text { Seedling } \\
\text { survival }_{\text {pred }}\end{array}$} & Intercept & 0.568 & 0.384 & 0.800 & 1.225 & 0.582 & 0.499 & 1.014 & 0.281 & 0.827 \\
\hline & $\begin{array}{l}\text { Slope (initial } \\
\text { density) }\end{array}$ & 0.736 & 0.078 & & 0.502 & 0.107 & & 0.601 & 0.058 & \\
\hline \multirow[t]{2}{*}{$\begin{array}{l}\text { Seedling } \\
\text { survival }\end{array}$} & Intercept & 0.521 & 0.582 & 0.834 & 1.495 & 0.504 & 0.583 & 1.192 & 0.412 & 0.746 \\
\hline & $\begin{array}{l}\text { Slope (initial } \\
\text { density) }\end{array}$ & 0.769 & 0.107 & & 0.472 & 0.085 & & 0.572 & 0.071 & \\
\hline \multirow{2}{*}{$\begin{array}{c}\text { Seed } \\
\text { production }_{\text {pred }}\end{array}$} & Intercept & 6.759 & 0.449 & 0.674 & 11.250 & 0.099 & & 11.648 & 0.104 & \\
\hline & $\begin{array}{l}\text { Slope (initial } \\
\text { density) }\end{array}$ & 0.726 & 0.107 & & & & & & & \\
\hline $\begin{array}{c}\text { Seed } \\
\text { production }\end{array}$ & Intercept & 10.851 & 0.079 & & 11.530 & 0.104 & & 11.712 & 0.121 & \\
\hline \multirow[t]{2}{*}{ Fecundity $_{\text {pred }}$} & Intercept & 6.759 & 0.449 & $0.227^{*}$ & 10.528 & 1.037 & 0.307 & 11.371 & 0.804 & 0.481 \\
\hline & $\begin{array}{l}\text { Slope (initial } \\
\text { density) }\end{array}$ & -0.274 & 0.107 & & -0.817 & 0.262 & & -0.928 & 0.206 & \\
\hline \multirow[t]{2}{*}{ Fecuncity } & Intercept & 11.051 & 0.600 & 0.766 & 12.427 & 1.226 & 0.454 & 10.983 & 0.936 & 0.425 \\
\hline & $\begin{array}{l}\text { Slope (initial } \\
\text { density) }\end{array}$ & -1.041 & 0.122 & & -1.220 & 0.285 & & -0.837 & 0.208 & \\
\hline
\end{tabular}

$R^{2}$-value with an asterisk $\left.{ }^{*}\right)$ indicates that seed predation made a significant difference within the relevant life stage $(p<0.05)$.

In all three fields, the number of adult plants was not affected by seed predation (Figure 1). Negative density-dependent processes regulated the transition from seedlings $\mathrm{m}^{-2}$ to adult plants $\mathrm{m}^{-2}$ (Table 1 ) in all three fields. Seedling mortality was higher in the absence than in the presence of seed predation (Figure 2).

In field 1, fewer seeds were produced per plant in the presence of seed predation. However, fecundity did not differ between fields 2 and 3 . In all three fields, fecundity was negatively density-dependent (Table 1). The level of plant mortality was higher in field 1 than in fields 2 and 3. Density-dependent plant mortality was higher in the absence than in the presence of seed predation in field 3 (Figure 2).

Seed production $\mathrm{m}^{-2}$ was influenced neither by seed predation nor by the density of adult plants, except in field 1 where seed production $\mathrm{m}^{-2}$ was lower in the presence than in the absence of seed predation, and negatively density-dependent (Figure 1; Table 1). The estimated seed production $\mathrm{m}^{-2}$ varied between the fields, i.e., lowest in field $1\left(51,621\right.$ seeds $\left.\mathrm{m}^{-2}\right)$, intermediate in field $2\left(101,744\right.$ seeds $\left.\mathrm{m}^{-2}\right)$, and highest in field $3\left(122,098\right.$ seeds $\left.\mathrm{m}^{-2}\right)$. 


\section{Discussion}

\subsection{Targeting the Seed Stage Affects the Density of the Subsequent Seedling Stage}

As expected in the first hypothesis, mortality at the seed stage affected the subsequent seedling stage. In addition, the high mortality of seeds due to seed predation $(\leq 77 \%$ seeds removed from experimental plots [12]) limited seedling emergence by 26 to $69 \%$. These patterns are in contrast to the findings of Blubaugh \& Kaplan [20]. Blubaugh and Kaplan [20] followed the fate of Chenopodium album L. seeds in the presence of seed predators. They found that in the presence of seed predators, seedling emergence was limited by $38 \%$ only. Our study, and the one of Blubaugh and Kaplan [20], differed in the size of the ambient seedbank. We measured the effect of seed losses on the seedling stage exclusively with freshly applied seeds, as there was no ambient seedbank of E. crus-galli in our experimental fields. This is the case when maize is introduced to the crop sequence. Here, weed species communities alter immediately, and especially E. crus-galli benefits [29]. Blubaugh and Kaplan [20], in contrast, conducted their experiment in a field that carried an ambient seedbank of 15,000 C. album seeds $\mathrm{m}^{-2}$. Thus, seedlings emerged from both newly-shed seeds and older seeds in the ambient seedbank, which were protected from seed predation which happens on the soil surface. This implies that mortality at the seed stage limits seedling emergence, but the strength of the limitation depends on the size of the ambient seed bank.

\subsection{Density-Dependent Mortality Compensates a Low Abundance of Seedlings}

Seedling abundance was partly compensated by density-dependent mortality in subsequent life stages. As expressed in our second hypothesis, mortality at the seed stage limited the abundance of seedlings ( $\leq 69 \%)$, but this effect was mitigated in subsequent life stages, namely adult plants, seed production per unit area (except in field 1), and fecundity. These results are similar to those from a study demonstrating the life cycle of an invasive plant species (Centaurea solstitialis L.) in the presence of pre-dispersal seed predation that targeted seeds on the plant before seed-shed [38]. Garren and Strauss [38] showed that seed losses were compensated in the subsequent vegetative period.

The summer-annual weed species E. crus-galli compensated seed losses through density-dependence in seedling emergence, seedling survival and fecundity. Densitydependent regulation in E. crus-galli in these life-stages is in line with findings in other annual weed species, i.e., Veronica hederifolia L., Papaver rhoeas L., Fumaria officinalis L., and Capsella bursa-pastoris (L.) Medik. [39]. In our study, plant populations responded to seed losses by different mortality rates in subsequent life-cycle transitions. The latter means in terms of seedling mortality, that the mortality of seedlings in E. crus-galli populations without seed loss through seed predation was higher than in populations with seed loss. Finally, seed production $\mathrm{m}^{-2}$ was constant in all populations of E. crus-galli.

In summary, although the number of seedlings, adult plants, and seed production $\mathrm{m}^{-2}$ differed between the fields, density-dependent seedling survival and fecundity regulated the populations of E. crus-galli and lead to a constant final seed production in all three maize fields.

\subsection{The Amount of the Final Seed Production Did Not Depend on Seed Predation}

In contrast to what we had expected in our third hypothesis, the final seed production in E. crus-galli populations did not depend on a high level of seed losses by seed predation. Demographic processes compensated the losses in E. crus-galli populations in maize fields. Analysis in field 1, however, showed that seed losses by seed predation in autumn and winter effect the final seed production of E. crus-galli in the subsequent year. If seed predation were the reason, we would expect that seed predation would effect life stages prior to seed production, namely seedling and adult plant life stages. Thus, the number of seedling and adult plants would have been lower in the presence of seed predators. In field 1 , however, the number of adult plants differed neither in the presence nor in the absence of seed predators. This suggests that seed predators did not cause differences in seed 
production. The differences in seed production in field 1 could rather be a consequence of given conditions due to the prevailing soils in the field. From field 1 over field 2 to field 3 , the soils differed from sand over loamy sand to sandy loam. The different quality of the soils can be the reason for the varying amount of the constant final seed production of E. crus-galli between the fields. The constant final seed production increased from field 1 to field 3. In each field, the E. crus-galli population fits through the level of seedling mortality and the per capita seed number. In field 1 , seedling mortality was low, while individual plants set a comparably low number of seeds. In fields 2 and 3 , in contrast, both seedling mortality and fecundity were higher than in field 1 . Our results are in line with findings on Ambrosia trifida L., in which in-field conditions strongly influenced life-cycle transitions, i.e., seedling mortality and loss of fecundity [40]. In field 1, we observed that soil moisture was lower than in fields 2 and 3. Furthermore, the total plant biomass of our populations was lower in field 1 than in fields 2 and 3 [41]. The low soil moisture hampers individual plant growth, biomass [42], and related fecundity [43,44], and, thus, the constant final seed production per unit area.

\subsection{Implications for Weed Management}

Evaluating our results from an agricultural perspective, the main issue for integrated weed management is to maintain the abundance of seedlings under a certain threshold. For E. crus-galli in maize fields in Germany, a threshold level is given (e.g., six seedlings according to [45]). In our study, seed predation affected the number of seedlings, but failed to keep the weeds below this threshold. To accelerate seed predation, farmers can extend the period of access to seeds on the soil surface for predators. Delaying the time of crop harvest, for example, increases this period. A cover crop under sown in maize can provide a canopy protecting seed feeders from being predated by a higher taxa and seeds from being incorporated in the soil by rain splashes. For controlling weeds, however, simply relying on targeting the seed stage by seed predation is not enough, as weeds can compensate for the losses. To limit the growth of a plant population, several studies suggested an 80 to $100 \%$ reduction in transitions between all life stages $[17,28,46]$. Model analysis testing the effect of multiple weed management strategies to reduce the reliance on herbicides in Abutilon theophrasti Medik. populations indicated that seed predation of $40 \%$, combined with crop rotation, reduced herbicide use, and no-till, reduced the population [17]. Therefore, efficient weed control should target many life stages, rather than focus on the seed stage only. Additional management strategies are useful to keep the number of weeds low even in other development stages. In maize crops, for example, farmers mainly use herbicides to control weeds at the seedling stage. In modern and integrated weed management, however, one of the principles is to use as little herbicide as possible [47]. Seed predation reduces the entry of new seeds into the seedbank, and thus the number of emerging seedlings. This improves the efficiency of herbicides because herbicides target weed plants at low densities better than at high densities [48]. Thus, mortality at the seed stage can indirectly reduce the use of herbicides.

Furthermore, our results illustrate the consequences of insufficient management strategies targeting the seedling stage. We assume that if E. crus-galli seedlings $\mathrm{m}^{-2}$ escape weed management in maize crops, populations compensate for the targeted seedlings. The reasons for weeds escaping management strategies are diverse, but failed herbicide application is one of the most intractable problems. Escaped seedlings will increase the weed population towards a constant final seed production. Our results give new insights that help farmers to understand the behavior of E. crus-galli if management fails.

Author Contributions: Conceptualization, H.P., P.R.W., F.D.M. and B.G.; methodology, H.P., P.R.W., F.D.M. and B.G.; validation, H.P. and F.D.M.; formal analysis, H.P. and F.D.M.; investigation, H.P., P.R.W., F.D.M. and B.G.; writing — original draft preparation, H.P., P.R.W., F.D.M. and B.G.; writingreview and editing, H.P., P.R.W., F.D.M. and B.G.; visualization, H.P. and F.D.M.; supervision, P.R.W., F.D.M. and B.G.; project administration, P.R.W. and B.G.; funding acquisition, P.R.W. and B.G. All authors have read and agreed to the published version of the manuscript. 
Funding: This research was funded by The German Research Foundation DFG, grant number WE 5040/2-1.

Institutional Review Board Statement: Not applicable.

Informed Consent Statement: Not applicable.

Data Availability Statement: Data are available by request to the last author.

Acknowledgments: We would like to thank the farmers Florian Wulff, Enrico Wessler, Jochen Walther, Ralf Lampe, Iman Geluk and Sebastian Eckhard for generously allowing us to use their fields. Also, many thanks to Christian Selig, Ingolf Gliege, Rosa Minderlen, and numerous student assistants for their hard work in the field and laboratory. We thank the German Research Foundation (DFG) for financial support for the project (WE 5040/2-1) 'Testing for the weed control potential of seed predators in agroecosystems'.

Conflicts of Interest: The authors declare no conflict of interest.

\section{Appendix A}

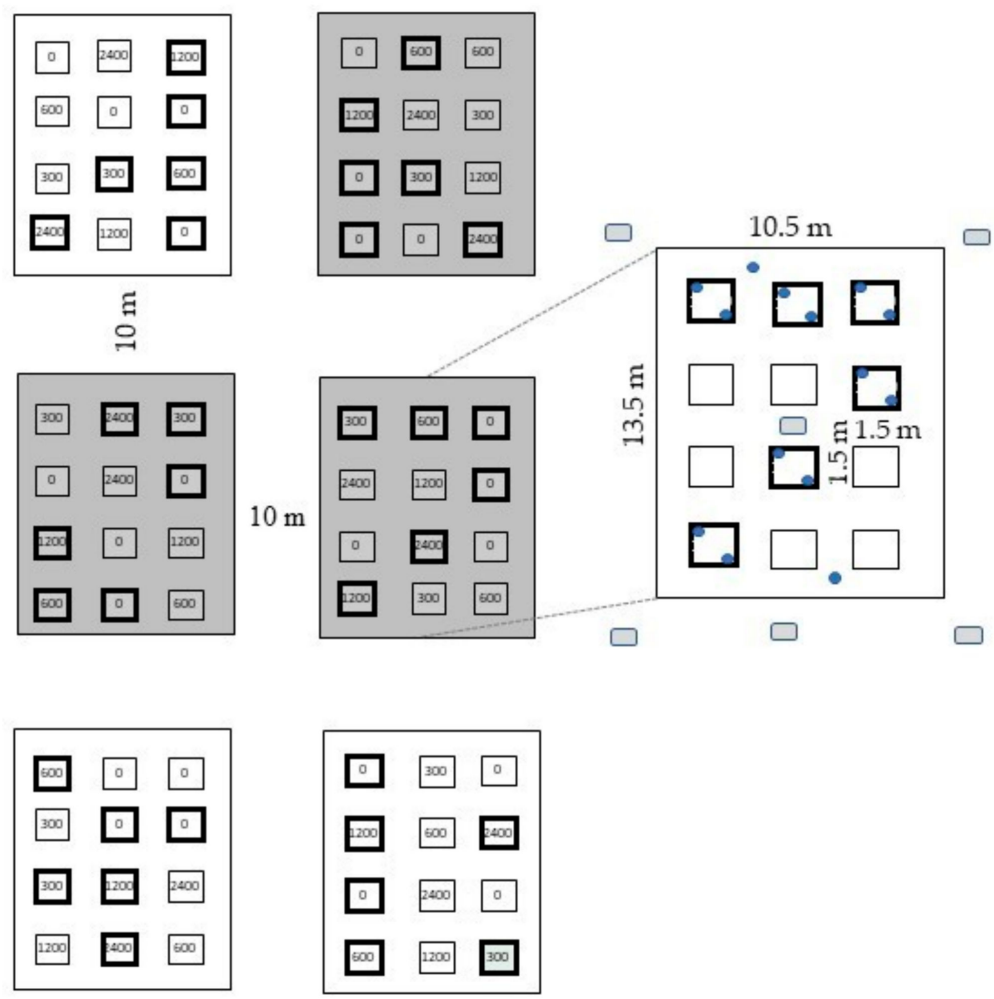

Figure A1. Experimental design showing the arrangement of the six blocks. In three blocks (grey) intraspecific competition and in the other three blocks (white) interspecific competion was initiated. Each block consist of 12 plots where half of them is surrounded by a plastic frame to prevent the acces of seed predators. Seed predators were trapped using Pitfall and Sherman life traps. In each plot we sowed a different density of E. crus-galli indicated by the number 0, 300, 600, 1200, 2400 seeds m$^{-2}$. 
Table A1. Analysis of variance (type 3) of the best-selected linear regression model to describe the log number of a life stage (seedlings $\mathrm{m}^{-2}$, adult plants $\mathrm{m}^{-2}$, fecundity, seed production $\mathrm{m}^{-2}$ ) and other explaining variables (field, log previous life-stage, weed seed predation, and first-order interactions).

\begin{tabular}{|c|c|c|c|c|}
\hline Life-Stage Parameter & Explaining Parameter & df & $F$ Value & $p$ Value \\
\hline \multicolumn{5}{|l|}{$\log \left(\right.$ seedlings $\left.\mathrm{m}^{-2}\right)$} \\
\hline \multirow[t]{7}{*}{$R^{2}=81 \%$} & intercept & 1 & 5.938 & 0.016 \\
\hline & field & 2 & 11.470 & $<0.001$ \\
\hline & $\log \left(\right.$ spring seedbank $\left.\mathrm{m}^{-2}\right)$ & 1 & 80.576 & $<0.001$ \\
\hline & predation & 1 & 20.037 & $<0.001$ \\
\hline & field $\times \log \left(\right.$ spring seedbank $\left.\mathrm{m}^{-2}\right)$ & 2 & 7.153 & 0.001 \\
\hline & field $\times$ predation & 2 & 4.909 & 0.009 \\
\hline & residuals & 135 & & \\
\hline \multicolumn{5}{|l|}{$\log \left(\right.$ adult plants $\mathrm{m}^{-2}$ ) } \\
\hline \multirow[t]{5}{*}{$R^{2}=81 \%$} & intercept & 1 & 10.123 & 0.001 \\
\hline & field & 2 & 2.645 & 0.075 \\
\hline & $\log \left(\right.$ seedlings $\left.\mathrm{m}^{-2}\right)$ & 1 & 63.533 & $<0.001$ \\
\hline & field $\times \log \left(\right.$ seedlings $\left.\mathrm{m}^{-2}\right)$ & 2 & 7.388 & $<0.001$ \\
\hline & residuals & 138 & & \\
\hline \multicolumn{5}{|l|}{$\log ($ fecundity) } \\
\hline \multirow[t]{9}{*}{$R^{2}=92 \%$} & intercept & 1 & 358.929 & $<0.001$ \\
\hline & field & 2 & 18.224 & $<0.001$ \\
\hline & $\log \left(\right.$ adult plants $\left.\mathrm{m}^{-2}\right)$ & 1 & 75.644 & $<0.001$ \\
\hline & predation & 1 & 6.780 & 0.010 \\
\hline & $\log \left(\text { adult plants } \mathrm{m}^{-2}\right)^{2}$ & 1 & 24.489 & $<0.001$ \\
\hline & $\log \left(\text { adult plants } \mathrm{m}^{-2}\right)^{2} \times$ predation & 1 & 4.197 & 0.043 \\
\hline & field $\times \log \left(\right.$ adult plants $\left.\mathrm{m}^{-2}\right)$ & 2 & 5.243 & 0.006 \\
\hline & field $\times$ predation & 2 & 8.150 & $<0.001$ \\
\hline & residuals & 133 & & \\
\hline \multicolumn{5}{|l|}{$\begin{array}{c}\log (\text { seed } \\
\left.\text { production } \mathrm{m}^{-2}\right)\end{array}$} \\
\hline \multirow[t]{6}{*}{$R^{2}=64 \%$} & intercept & 1 & 1028.152 & $<0.001$ \\
\hline & field & 2 & 94.102 & $<0.001$ \\
\hline & $\log \left(\right.$ adult plants $\left.\mathrm{m}^{-2}\right)$ & 1 & 8.547 & 0.004 \\
\hline & predation & 1 & 1.799 & 0.182 \\
\hline & field $\times$ predation & 2 & 12.162 & $<0.001$ \\
\hline & residuals & 137 & & \\
\hline
\end{tabular}

\section{References}

1. Cousens, R.; Mortimer, M. Dynamics of Weed Populations; Cambridge University Press: Cambridge, CA, USA, 1995.

2. Davis, A.S. When does it make sense to target the weed seed bank? Weed Sci. 2006, 54, 558-565. [CrossRef]

3. Gallandt, E.R. How can we target the weed seedbank? Weed Sci. 2006, 54, 588-596. [CrossRef]

4. Westerman, P.R.; Dixon, P.M.; Liebman, M. Burial rates of surrogate seeds in arable fields. Weed Res. 2009, 49, 142-152. [CrossRef]

5. Davis, A.S.; Daedlow, D.; Schutte, B.J.; Westerman, P.R. Temporal scaling of episodic point estimates of seed predation to long-term predation rates. Methods Ecol. Evol. 2011, 2, 682-890. [CrossRef]

6. Westerman, P.R.; Wes, J.S.; Kropff, M.J.; van der Werf, W. Annual losses of weed seeds due to predation in organic cereal fields. J. Appl. Ecol. 2003, 40, 824-836. [CrossRef]

7. Gaba, S.; Deroulers, P.; Bretagnolle, F.; Bretagnolle, V. Lipid content drives weed seed consumption by ground beetles (Coleopterea, Carabidae) within the smallest seeds. Weed Res. 2019, 59, 170-179. [CrossRef]

8. Moles, A.T.; Warton, D.I.; Westoby, M. Do small-seeded species have higher survival through seed predation than large-seeded species? Ecology 2003, 84, 3148-3161. [CrossRef]

9. Westerman, P.R.; Borza, J.K.; Andjelkovic, J.; Liebman, M.; Danielson, B. Density-dependent predation of weed seeds in maize fields. J. Appl. Ecol. 2008, 45, 1612-1620. [CrossRef]

10. Daedlow, D.; Westerman, P.R.; Baraibar, B.; Rouphael, S.; Gerowitt, B. Weed seed predation rate in cereals as a function of seed density and patch size, under high predation pressure by rodents. Weed Res. 2014, 54, 186-195. [CrossRef]

11. Baraibar, B.; Daedlow, D.; de Mol, F.; Gerowitt, B. Density dependence of weed seed predation by invertebrates and vertebrates in winter wheat. Weed Res. 2012, 52, 79-87. [CrossRef] 
12. Pannwitt, H.; Westerman, P.R.; de Mol, F.; Selig, C.; Gerowitt, B. Biological control of weed patches by seed predators; responses to seed density and exposure time. Biol. Control 2017, 108, 1-8. [CrossRef]

13. Hulme, P.E. Post-dispersal seed predation in grassland: Its magnitude and sources of variation. J. Ecol. 1994, 82, 645. [CrossRef]

14. Trichard, A.; Alignier, A.; Biju-Duval, L.; Petit, S. The relative effects of local management and landscape context on weed seed predation and carabid functional groups. Basic Appl. Ecol. 2013, 14, 235-245. [CrossRef]

15. Petit, S.; Trichard, A.; Biju-Duval, L.; McLaughlin, Ó.; Bohan, D.A. Interactions between conservation agricultural practice and landscape composition promote weed seed predation by invertebrates. Agric. Ecosyst. Environ. 2017, 240, 45-53. [CrossRef]

16. Fischer, C.; Thies, C.; Tscharntke, T. Mixed effects of landscape complexity and farming practice on weed seed removal. Perspect. Plant Ecol. Evol. Syst. 2011, 13, 297-303. [CrossRef]

17. Westerman, P.R.; Liebman, M.; Menalled, F.D.; Heggenstaller, A.H.; Hartzler, R.G.; Dixon, P.M. Are many little hammers effective? Velvetleaf (Abutilon theophrasti) population dynamics in two- and four-year crop rotation systems. Weed Sci. 2005, 53, $382-392$. [CrossRef]

18. Firbank, L.G.; Watkinson, A.R. On the analysis of competition within two-species mixtures of plants. J. Appl. Ecol. 1985, $22,503$. [CrossRef]

19. White, S.S.; Renner, K.A.; Menalled, F.D.; Landis, D.A. Feeding preferences of weed seed predators and effect on weed emergence. Weed Sci. 2007, 55, 606-612. [CrossRef]

20. Blubaugh, C.K.; Kaplan, I. Invertebrate seed predators reduce weed emergence following seed rain. Weed Sci. 2016, 64, 80-86 [CrossRef]

21. Petit, S.; Cordeau, S.; Chauvel, B.; Bohan, D.A.; Guillemin, J.-P.; Steinberg, C. Biodiversity-based options for arable weed management. A review. Agron. Sustain. Dev. 2018, 38, 551. [CrossRef]

22. Larios, L.; Pearson, D.E.; Maron, J.L. Incorporating the effects of generalist seed predators into plant community theory. Funct. Ecol. 2017, 31, 1856-1867. [CrossRef]

23. Hulme, P.E. Post-dispersal seed predation: Consequences for plant demography and evolution. Perspect. Plant Ecol. Evol. Syst. 1998, 1, 32-46. [CrossRef]

24. Holst, N.; Rasmussen, I.A.; Bastiaans, L. Field weed population dynamics: A review of model approaches and applications. Weed Res. 2007, 47, 1-14. [CrossRef]

25. Watkinson, A.R.; Freckleton, R.P.; Forrester, L. Population dynamics of Vulpia ciliata: Regional, patch and local dynamics. J. Ecol. 2000, 88, 1012-1029. [CrossRef]

26. Palmblad, I.G. Competition in experimental populations of weeds with emphasis on the regulation of population size. Ecology 1968, 49, 26-34. [CrossRef]

27. Yoda, K.; Kira, T.; Ogawa, H.; Hozumi, K. Self-thinning in overcrowded pure stands under cultivated and natural conditions. J. Biol. Osaka City Univ. 1963, 14, 107-129.

28. Buckley, Y.M.; Hinz, H.L.; Matthies, D.; Rees, M. Interactions between density-dependent processes, population dynamics and control of an invasive plant species, Tripleurospermum perforatum (scentless chamomile). Ecol. Lett. 2001, 4, 551-558. [CrossRef]

29. Von Redwitz, C.; Gerowitt, B. Maize-dominated crop sequences in northern Germany: Reaction of the weed species communities. Appl. Veg. Sci. 2018, 21, 431-441. [CrossRef]

30. Maun, M.A.; Barrett, S.C.H. The Biology of Canadian Weeds.: 77. Echinochloa crus-galli (L.) Beauv. Can. J. Plant Sci. 1986, 66, 739-759. [CrossRef]

31. Norris, R.F. Case history for weed competition/population ecology: Barnyardgrass (Echinochloa crus-galli) in sugarbeets (Beta vulgaris). Weed Technol. 1992, 220-227. [CrossRef]

32. Pannwitt, H.; Westerman, P.R.; de Mol, F.; Gerowitt, B. Using panicle dry weight to estimate seed production in Echinochloa crus-galli. Weed Res. 2019, 150, 717. [CrossRef]

33. Claerhout, S.; Reheul, D.; de Cauwer, B. Sensitivity of Echinochloa crus-galli populations to maize herbicides: A comparison between cropping systems. Weed Res. 2015, 55, 470-481. [CrossRef]

34. Wiles, L.J.; Barlin, D.H.; Schweizer, E.E.; Duke, H.R.; Whitt, D.E. A new soil sampler and elutriator for collecting and extracting weed seeds from soil. Weed Technol. 1996, 10, 35-41. [CrossRef]

35. Thompson, K.; Bakker, J.P.; Bekker, R.M. Soil Seedbank of North West Europe: Methodology, Density and Longevity; Cambridge University Press: Cambridge, CA, USA, 1997; ISBN 0521495199.

36. Begon, M.; Townsend, C.R.; Harper, J.L. Ecology: From Individuals to Ecosystems, 4th ed.; Blackwell: Malden, MA, USA, 2006; ISBN 9781405111171.

37. R Core Team. R: A Language and Environment for Statistical Computing. Available online: https://www.R-project.org/ (accessed on 2 March 2018).

38. Garren, J.M.; Strauss, S.Y. Population-level compensation by an invasive thistle thwarts biological control from seed predators. Ecol. Appl. 2009, 19, 709-721. [CrossRef]

39. García de León, D.; Freckleton, R.P.; Lima, M.; Navarrete, L.; Castellanos, E.; González-Andújar, J.L. Identifying the effect of density dependence, agricultural practices and climate variables on the long-term dynamics of weed populations. Weed Res. 2014, 54, 556-564. [CrossRef] 
40. Wortman, S.E.; Davis, A.S.; Schutte, B.J.; Lindquist, J.L.; Cardina, J.; Felix, J.; Sprague, C.L.; Dille, J.A.; Ramirez, A.H.M.; Reicks, G.; et al. Local conditions, not regional gradients, drive demographic variation of giant ragweed (Ambrosia trifida) and common sunflower (Helianthus annuus) across Northern U.S. maize Belt. Weed Sci. 2012, 60, 440-450. [CrossRef]

41. Selig, C.; de Mol, F.; Gerowitt, B. Echinochloa kompensiert Keimlingsverluste durch erhöhte Biomasseproduktion. Jul. Kühn Arch. 2018, 458, 435-441. [CrossRef]

42. Wiese, A.F.; Vandiver, C.W. Soil Moisture Effects on Competitive Ability of Weeds. Weed Sci. 1970, 18, 518-519. [CrossRef]

43. Thompson, B.K.; Weiner, J.; Warwick, S.I. Size-dependent reproductive output in agricultural weeds. Can. J. Bot. 1991, 69, 442-446. [CrossRef]

44. Weiner, J.; Campbell, L.G.; Pino, J.; Echarte, L. The allometry of reproduction within plant populations. J. Ecol. 2009, 97, 1220-1233. [CrossRef]

45. Lfl Bayern. Unkraut-Steckbriefe-Hühner-Hirse. Available online: https://www.lfl.bayern.de/ips/unkraut/u_steckbriefe/0539 55/index.php (accessed on 3 May 2019).

46. Ramula, S.; Buckley, Y.M. Management recommendations for short-lived weeds depend on model structure and explicit characterization of density dependence. Methods Ecol. Evol. 2010, 1, 158-167. [CrossRef]

47. Barzman, M.; Bàrberi, P.; Birch, A.N.E.; Boonekamp, P.; Dachbrodt-Saaydeh, S.; Graf, B.; Hommel, B.; Jensen, J.E.; Kiss, J.; Kudsk, P.; et al. Eight principles of integrated pest management. Agron. Sustain. Dev. 2015, 35, 1199-1215. [CrossRef]

48. Taylor, K.L.; Hartzler, R.G. Effect of seed sank augmentation on herbicide efficacy. Weed Technol. 2000, 14, 261-267. [CrossRef] 